\title{
HONORING AND UTILIZING \\ THE PREOPERATIONAL THINKERS' ARTISTIC PROCESSES \\ IN ART EDUCATION
}

A Thesis Presented

By

J.B. Paquette

Approved:

Cheryl L. Williams, Ph.D.

Committee Chair

Donna Darling Kelly, Ph.D.

Committee Member

Mary Ellen McGuire-Schwartz, Ed.D.

Committee Member

Heemong Kim, Professor

Chair, Department of Art

Richard R. Weiner, Ph.D.

Dean, Faculty of Arts and Sciences

Dr. Carmen R. Giebelhaus

Associate Dean, Teacher Education

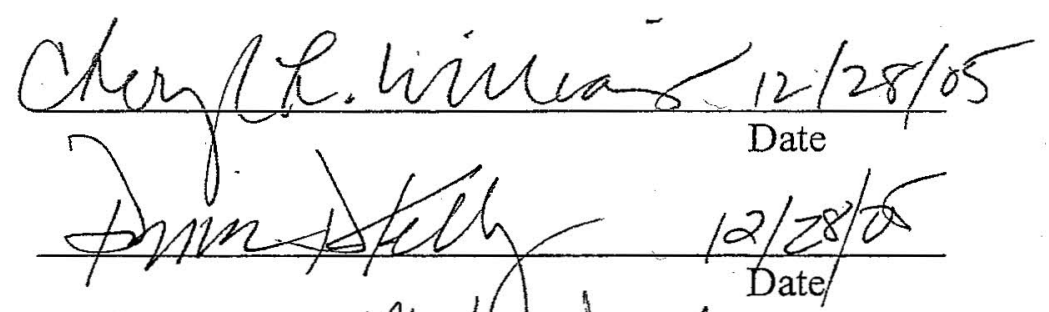

Feinstein School of Education and Human Development

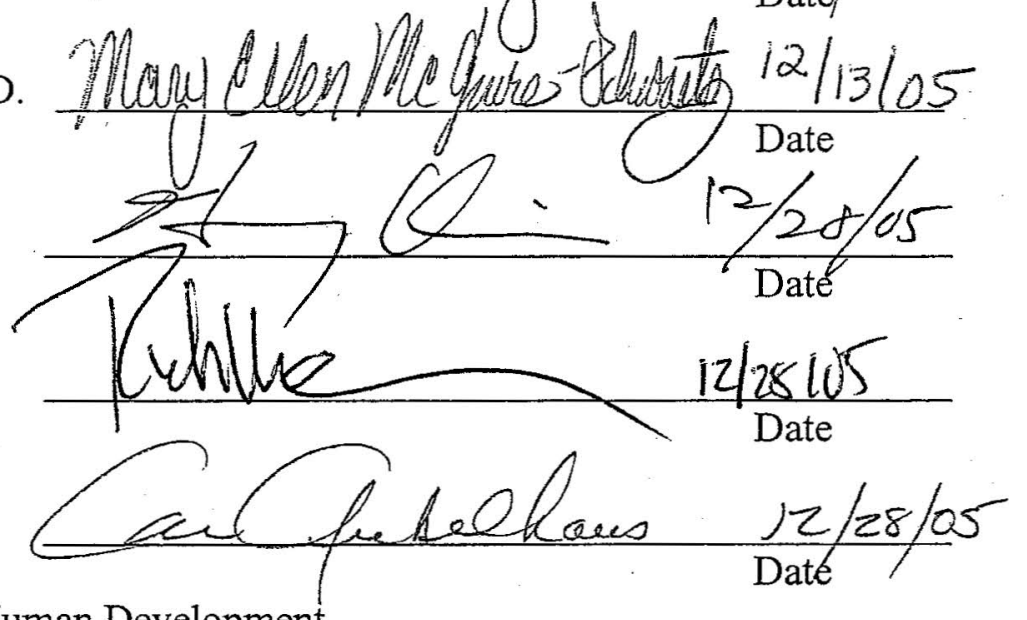

